Board of Governors of the Federal Reserve System

International Finance Discussion Papers

Number 662

March 2000

\title{
CAPITAL CONTROLS DURING FINANCIAL CRISES: THE CASE OF MALAYSIA AND THAILAND
}

Hali J. Edison and Carmen M. Reinhart

NOTE: International Finance Discussion Papers are preliminary materials circulated to stimulate discussion and critical comment. References to International Finance Discussion Papers (other than an acknowledgment that the writer has had access to unpublished material) should be cleared with the author or authors. Recent IFDPs are available on the Web at www.bog.frb.fed.us. 


\title{
CAPITAL CONTROLS DURING FINANCIAL CRISES: THE CASE OF MALAYSIA AND THAILAND
}

\author{
Hali J. Edison and Carmen M. Reinhart*
}

\begin{abstract}
This study examines the impact capital controls had in Malaysia (1998-1999) and Thailand (1997). We aim to assess the extent to which the capital controls were effective in delivering the outcomes that motivated their imposition. We conclude that in Thailand the controls did not deliver much of what was intended--although, one does not observe the counterfactual. By contrast, in the case of Malaysia the controls did align closely with the priors of what controls are intended to achieve: greater interest rate and exchange rate stability and more policy autonomy.
\end{abstract}

Keywords: Capital Controls, Capital Flows, Financial Crises, Asian Currency Crisis, CrossBorder Volatility, Malaysia, and Thailand.

JEL classification: F21 and F32

* The first author is a senior economist in the Division of International Finance, Board of Governors of the Federal Reserve System, Washington, D.C. 20551 U.S.A. and the second author is a Research Associate of the NBER and a Professor of Public Policy, School of Public Policy, University of Maryland, College Park, Maryland 20742. The authors may be reached on the Internet at hali.edison@frb.gov and reinhart@econ.umd.edu , respectively. ( Related research is available from the second author's home page: www.puaf.umd.edu/papers/reinhart.htm). The views in this paper are solely the responsibility of the authors and should not be interpreted as reflecting the views of the Board of Governors of the Federal Reserve System or any other person associated with the Federal Reserve System. This paper was prepared for the Federal Reserve Bank of San Francisco 1999 Pacific Basin Conference on "Financial Crises in Emerging Markets," September 23-24, 1999. The authors wish to thank Vincent Reinhart for very helpful comments and suggestions. We also thank Gary Lee and Frank Warnock for providing us the US TIC data and Rafael Romeu, Hayden Smith, and Michael Sharkey for excellent research assistance. 


\section{Introduction}

In the 1990s net capital inflows to developing countries grew substantially, particularly to those countries that had liberalized their capital accounts. As countries experienced surges in capital flows, the debate on how to manage these surges became a pressing policy topic. Capital controls when they were discussed at all, were examined in the context of liberalizing restrictions on capital outflows, or in terms of which types of capital inflows should be taxed. However, with the most recent wave of financial market turbulence there has been a shift in the debate on capital controls. The types of controls that were contemplated or used during the recent crises were very different from the measures introduced during the inflow phase of the capital flow cycle. ${ }^{1}$ These types of controls are applied mainly to outflows and are viewed as "last resort" measures as opposed to controls being applied to inflows which were interpreted as "prudential."

Controls on capital outflows have been advocated as a way of dealing with financial and currency crises. These controls can take a number of forms: restrictions on capital account transactions including taxes on funds remitted abroad, outright prohibition of funds' transfers, dual exchange rates and outright prohibition of cross-border movement of funds. ${ }^{2}$ The idea behind these measures is that they help slow down the drainage of international reserves and capital outflows and give the authorities time to implement corrective policies. Paul Krugman (1998) has argued that countries facing major crisis might benefit from temporary imposition of controls on outflows, by giving the country the time to lower their domestic interest rates and put

\footnotetext{
${ }^{1}$ See Reinhart and Smith (1998)
}

${ }^{2}$ The measures may also be more subtle. For instance, in early 1999 Brazil increased the share of local financial firm's portfolio that must be held in domestic sovereign bonds (see Edison and Reinhart, 1999 for details). 
into place a pro-growth package. ${ }^{3}$ Malaysia and, for a short while, Thailand followed this path in 1997-99.

The initial reaction to the imposition of controls, especially for Malaysia, was quite negative. Subsequently, however, Malaysia seems to have fared reasonably well--although not as well as Korea, which did not introduce new restrictions on capital movements. Furthermore, institutional investors appear to have short memories, as Malaysia's controls do not seem to have reduced investors' appetite for returning to Malay capital markets once controls were eased. To quote a recent article on Malaysia...

"Stocks of companies that were sold off two years ago and criticized for crony capitalist practices are being snapped up by foreign buyers at a fevered pace. Most companies have done little to address the flaws that foreign investors decried at the time. Almost all companies are under the same management as they were then."

Thomas Fuller, International Herald Tribune, Paris, January 18, 2000.

Not surprisingly, the use of such "market unfriendly" measures in times of stress is receiving considerable attention among academic and policy circles. The purpose of this study is to examine systematically two crisis-capital control episodes, Malaysia 1998-1999, and Thailand 1997--in greater detail. We aim to assess the extent to which the capital controls were effective and successful in delivering some of the outcomes that motivated their inception in the first place.

For our case studies, we look at two types of data. First, we study monthly data. We

${ }^{3}$ For example, after the introduction of capital controls in Malaysia other measures were introduced to stimulate the economy and reduce the burden of banks. 
focus on the movement of foreign exchange reserves and capital flows. In addition, we examine data from the United States International Capital Reports (TIC) to investigate how US portfolio flows changed in the aftermath of controls. This data spans January 1988 to March 1999. Second, we examine daily data covering the period January 1996 through July 23, 1999 for key financial variables including: interest rates, equity market returns, exchange rate changes, domestic-foreign interest rate differentials, and bid-ask spreads on foreign exchange.

We employ a variety of empirical tests to attempt to examine the effectiveness of capital controls. For the monthly data, we test for differences in basic descriptive statistics in the capital control and no control periods. For the daily data, we also consider tests for the equality of moments and changes in persistence to address changes in behavior of key financial variables. In addition, we test for changes in cross border volatility using GARCH tests for the effects of controls on volatility, as in Edwards (1998).

There are, of course, several limitations and concerns with the kind of analysis we undertake. First, results are episode specific--not "stylized facts." Second, given that these kinds of controls are introduced during periods of turbulence, it is particularly difficult to separate what owes to the controls and what is due to the financial crisis per se. For instance, a generalized withdrawal from risk-taking (as what followed the Russia/LTCM episode in the fall of 1998) can have similar implications and outcomes as the introduction of capital controls. ${ }^{4}$ Namely, international flows dry up, spreads widen, volatility in asset markets increases, and so on. In addition, our empirical methodology assumes linearities in relationships, which may break down during period of extreme market stress--an issue that is highlighted in multiple-equilibria

\footnotetext{
${ }^{4}$ See Kaminsky and Reinhart (2000).
} 
crises models. These caveats apply especially to analysis of the daily data but also to the monthly data we consider as well.

With these caveats in mind, our key empirical findings are summarized below. First, the monthly data on foreign reserves and capital flows highlight some of the differences in the Malay and Thai experiences with capital controls. The monthly results suggest that in Malaysia economic relationships changed; while in Thailand things seemed to continue to get worse. For example, foreign exchange reserves continued to fall during the period of capital controls in Thailand, while they increased immediately following the imposition of controls in Malaysia. ${ }^{5}$

Second, we find interest rates were less variable in both Malaysia and Thailand following the introduction of controls, but the level was lower only in Malaysia during the control period. Stock returns tended to be more variable following the introduction of capital controls--especially so in the case of Thailand--consistent with the view that more of the burden of adjustment falls on prices when the change in quantities is restricted. The exchange rate was more stable during the control period for Malaysia, while they were more variable for Thailand.

Third, as to the side-effects of capital controls, we find that foreign exchange bid-ask spreads were uniformly wider and more variable during the control periods. Also, onshoreoffshore interest rate spreads widened and become more volatile following the introduction of controls.

Fourth, our results suggest that there is little evidence that capital controls were effective in reducing volatility spillovers. In the case of Malaysia, the results suggest that capital controls

${ }^{5}$ As shown in Kaminsky, Lyons, and Schmukler (2000) and reproduced here, however, mutual fund flows to Malaysia turn sharply negative after the introduction of capital controls. 
dampened the spillover, but it did not eliminate the spillover, although this result was not robust across all model specifications.

The reminder of the paper is organized as follows. The next section discusses the reasons countries might apply controls and the theoretical predictions of the effects of those controls.

Section 3 describes the measures and their chronology in Malaysia and Thailand. The following two sections examine the effectiveness of capital controls, describing empirical tests performed, their outcomes, and their implications. First, we focus on monthly data, examining capital flows and other macroeconomic indicators. Then we consider daily data, assessing financial variables including interest rates, equity returns, and exchange rate changes. The final section discusses possible extensions and policy implications of the analysis.

\section{Theoretical Predictions of the Effects of Controls}

In this section, we first review some of the reasons most often voiced by policy makers for resorting to capital controls during periods of turbulence. Knowing what the stated expectations from the policy change are in the first place is essential to assess whether the policy was "effective" or "successful." Since many of these expectations are based on an implicit model, we then proceed to summarize the implications of capital controls for some of the variables of interest.

\subsection{Reasons for resorting to capital controls during crises periods}

The first line of defense by central banks dealing with speculative attacks on their currencies is usually to sell off their holdings of foreign exchange. However, central bank holdings of foreign exchange are often inadequate to support the currency and, even if the initial stock is high by international standards, recurring runs on the currency can quickly deplete the 
initial war chest. Not surprisingly, policy makers will often cite the need to stem the drain on foreign exchange reserves as a motivation for introducing capital controls during periods of extreme market stress.

Also central banks can (and often do) react to speculative pressures by raising interest rates, occasionally to prohibitively high levels. However, given the consequences of high interest rates on economic activity and debt servicing costs, this policy alternative is not particularly appealing either--especially if the pressures persist over an extended period and the domestic financial system is weak. Hence, capital controls are seen as a course of action which would enable the monetary authorities to maintain lower (and more stable) interest rates than would be the case under free capital mobility--especially if credibility has been lost. More generally, controls can (if they are effective) fulfill the authorities' desire to regain autonomy in monetary policy--without floating the exchange rate.

Since volatile international bond and equity portfolio flows are frequently viewed as a destabilizing force in asset markets and, more generally, in the financial system, another reason which is often cited for introducing controls is the desire to reduce the volatility in asset prices.

\subsection{Theoretical priors}

The Mundellian trinity suggests that fixed (or quasi fixed) exchange rates, independent monetary policy, and perfect capital mobility cannot be achieved simultaneously. Capital controls are a way of allowing the authorities to retain simultaneous control over the interest rate and the exchange rate. Capital controls may be particularly appealing when the authorities are reluctant to allow the exchange rate to float freely, which is the case in most emerging markets 
(EMs). ${ }^{6}$ Fear of floating may arise for a variety of reasons, including the dollarization of liabilities--but for the purposes at hand, however, those reasons are not central to our analysis. The important point for our analysis is that controls introduce a systematic wedge between domestic and foreign interest rates. As uncovered interest rate parity breaks down, the domestic policy interest rate (from the vantage point of a small open economy) need not follow international interest rates. ${ }^{7}$ In principle, variation in that wedge can be introduced by the authorities to influence the exchange rate systematically. One example of this is the theoretical model of Reinhart and Reinhart (1998), who trace out the effects of one of the simplest forms of capital controls--a reserve requirement. Depending on the degree of competition among financial intermediaries, Reinhart and Reinhart show that the wedge between foreign and domestic interest rates induced by the reserve requirement influences the response of the exchange rate and the real economy to shocks.

The potential consequences of capital controls become even more persuasive in models that provide an important role for asset stocks in affecting an economy. The general mechanism at work is that, if the flow of capital is restricted in any way, then the burden of adjustment in asset markets falls more on prices. Calvo and Rodriguez (1978) first showed how sluggishness in the flow of international assets can generate overshooting of the exchange rate. Reinhart (1998) broadened that model by incorporating equity prices and introducing three different kinds of restrictions on capital flows. The implication in Reinhart's framework is that equity price

${ }^{6}$ See Calvo and Reinhart (1999).

${ }^{7}$ Of course, imperfect asset substitutability and a time varying risk premia are sufficient to explain a breakdown of uncovered interest parity--even in the absence of capital controls. 
volatility should increase with the imposition of controls. A shock to the desired portfolio allocation generally triggers adjustments to both asset quantities and prices. Capital controls shift more of that adjustment toward prices and, to the extent that they introduce interest rate wedges, may also alter the relationship between asset prices and the policy rate.

Edison and Reinhart (1999), provide details about the predictions of theory for a host of financial variables. Some of the key predictions are as follows:

- The declines in foreign exchange reserves and the capital outflows should both either stop or reverse itself.

- The level of domestic interest rates should decline as high interest rates are no longer necessary to prevent capital outflows. There should also be a decline in interest rate volatility.

- The implications of a decline in market liquidity--whether owing to a capital control or a generalized withdrawal from risk taking-- are also straightforward. Bid-ask spreads in the market(s) where liquidity has diminished should widen and become more volatile.

\section{The Control Episodes}

In this section, we describe the timing and nature of the selected capital control episodes as well as some of the more relevant events surrounding the introduction and lifting of these measures.

\subsection{The policy measures and chronology of events}

The capital control episodes that we analyze are: Thailand (May 14, 1997-January 30, 1998) and Malaysia (September 1, 1998 to present). The chronology of the episodes and further details of the measures are summarized in Table1. We briefly discuss these episodes below. 
In the face of speculative attacks, the Thai authorities imposed capital controls in May 1997. The goal of these controls was to stabilize the foreign exchange market as speculative pressure continued to mount. The Bank of Thailand was concerned that using an interest rate defense as a means to defend the baht would have adverse effects on economic activity and the banking system. The capital control measures put in place were aimed at closing the channels for speculation; creating a two-tiered currency market. This system was aimed at denying speculators access to funds. The measures they used were not as sweeping as those the Malaysian subsequently put in place. However, the controls initially seemed to work as offshore interest rates rose above the domestic rates. The baht was floated on July 2, 1997 and controls were left in place until January 30, 1998.

In September 1998, the Malaysian authorities imposed a number of administrative exchange and capital control measures aimed at containing ringgit speculation and the outflow of capital. The measures sought to increase monetary independence and insulate the economy from potential shocks from the global economy, like Russia and LTCM. The Malaysian authorities were concerned that domestic interest rates would have to be kept unusually high for long periods of time, producing unhelpful effects on economic activity and the banking system. ${ }^{8}$ Hence in September they closed all channels for the transfer of ringgit abroad and required repatriation of ringgit held abroad to Malaysia. In addition they block the repatriation of portfolio capital held by nonresidents for 12 months, and imposed restrictions on transfer of capital by residents. These controls were supported by additional measures to eliminate

${ }^{8}$ It is important to consider the highly leveraged condition of the Malay economy at this time, with bank loan to GDP ratios of about one-hundred-and-sixty percent. 
loopholes. On February 4, 1999, the 12-month holding restriction was replaced with a declining scale of exit levies.

There are two obvious differences between the Thai and Malaysian experience. The first difference is that Thailand was undergoing speculative attacks and tried to use capital controls as a defense mechanism. In contrast, Malaysia was not undergoing extreme speculative pressure when they applied their controls. The second difference is that the Malaysian controls were broad and attempted to eliminate all obvious loopholes. In contrast, the controls Thailand put into place, at least in hindsight, were not comprehensive enough to eliminate the speculative pressure on the baht.

\section{The Effectiveness of Controls: Impact on Capital Flows}

In this section we attempt to describe broadly the economic situation prior to the application of capital controls and the subsequent developments, considering data on economic activity, foreign exchange reserves, interest rates, and exchange rates. In addition, we examine monthly capital flow data, using those data from the U.S. international Capital Transaction Report. The data on mutual fund flows is taken from the broader study of the patterns and determinants of these flows by Kaminsky, Lyons, and Schmukler (2000). The focus is on monthly data; consequently the empirical methods we use are descriptive in nature.

\subsection{Economic Performance}

There are a limited number of tests that one can use to analyze the monthly data as there are too few observations during the period of controls in both cases. Graphs and a quick look at some descriptive statistics illustrate vast differences in the results that capital controls appear to have yielded in Malaysia and Thailand. 
Figure 1 shows plots of data on industrial production, foreign exchange reserves, interest rates, and the exchange rate for Malaysia. Since September 1998, industrial production has increased more than 8 percent, despite dropping significantly after controls were initially applied. Foreign exchange reserves rose steadily up from $\$ 20$ billion in late August 1998 to $\$ 27$ billion in April 1999. Interest rates have fallen to below pre-crisis levels. In 1997, interest rates averaged just over 7 percent; in June 1999 these same 1-month interest rates were slightly more than 3 percent. In addition, the exchange rate which had started depreciating in July 1997 was stabilized by the authorities, pegging the rate against the dollar. Taken by themselves, these facts suggest that the capital controls may have helped Malaysia insulate its economy. Yet, the behavior of interest rates and economic activity of the other crisis-hit countries, Korea and Thailand, have also enjoyed many of these benefits around the same time as Malaysia. It is not clear whether these capital controls contributed to improving Malaysia's performance. At a minimum, this finding suggests that capital controls did not harm Malaysia--as some critics of the measures feared. However, as Figure 2 (taken from Kaminsky, Lyons, and Schmukler, 2000) suggest, in the month of September 1998 (labeled After the Russian Crisis--which began on August 17, 1998) Malaysia posted record outflows among the countries in the sample, casting a lukewarm reading on the success of the controls.

Figure 3 gives the same data for Thailand. A completely different story emerges when considering the economic performance of Thailand, following their use of capital controls. As noted earlier, Thailand applied capital controls in May 1997 hoping to prevent a full-blown currency crisis. In contrast to Malaysia, Thailand was not able to prevent the crisis and in fact some policymakers have argued that the capital controls may have exacerbated the problem for 
Thailand. Figure 3 shows that industrial output declined, foreign exchange reserves fell, interest rates rose and the exchange rate lost half of its value against the dollar. These observations suggest that capital controls failed to stop the currency crisis. It is important to note, however, that while Thailand introduced the controls in the midst of crisis, Malaysia's controls were introduced at a time in which financial markets had begun to settle. This difference in timing may also be a key factor in explaining the difference between the two countries' outcomes.

The top panels of Tables 2 and 3 provide descriptive statistics for (mean and standard errors) for foreign reserves and private capital flows for the two countries. The table also reports tests for the equality of first and second moments between capital control and free capital mobility. For Malaysia (Table 2) we find that the average level of foreign reserves is higher during the control episode, but this difference is not statistically significant. In Thailand (Table 3), we find that foreign reserves are, on average, lower during the capital controls period and that outflows are higher and more variable. The results for Thailand are statistically significant and are quite suggestive that controls did not insulate the Thai economy.

Figure 4 shows private capital flow data for Malaysia (upper panel) and Thailand (lower panel). Both figures are plotted in local currency -- ringgit for Malaysia and baht for Thailand. Unfortunately, the data for Malaysia are quarterly and end in 1998 Q4, owing to long reporting lags. It appears that the large capital outflows stopped following the application of capital controls. Note that there was also a huge capital outflow the third quarter of 1997, owing to the general crisis in Asia. The lower panel which shows capital flows for Thailand suggests that Thailand's capital controls were not effective in preventing outflows of capital. From May 1997 through the crisis capital outflows increased despite the use of capital controls. 


\subsection{Capital Flows to and from the United States: the TIC Data}

In this section we employ a data base on US capital flows to and from Malaysia and Thailand, starting in January 1988 and ending in March 1999. The frequency of the data is monthly and these times series were constructed using the International Capital Reports of the US Treasury Department. We consider four broad categories of flows in the capital account: equity flows, bond flows excluding official US flows (U.S. corporate and foreign bonds), all bond flows, and total flows. We construct both gross and net flows. Many studies seem to use net measures for equity and gross measures for bond flows. Gross bond flow measures tend to be used to abstract from the effect of sterilization policy actions and other types of reserve operations.

Once again we employ descriptive statistics in analyzing the data. The lower panels of table 2 and 3 report the results for Malaysia and Thailand, respectively. In the case of Malaysia, controls in general do not seem to be associated with lower capital flows to/from the United States. There is some indication that gross bond flows and especially equity flows were lower during the period of capital controls, but most of the time this difference was not statistically significant. This result might arise in part because the data focus exclusively on flows to and from the United States which was not heavily involved in Malaysia and in part because the period prior to the employment of controls lead to a significant amount of capital outflow and volatility.

The results for Thailand are suggestive that, if anything, capital flows increased during the period of capital controls. For example, gross flows on all bonds, nearly doubled during the control period. These flows rose on average from $\$ 1.5$ billion to over $\$ 3$ billion during the 
controls period. As noted earlier there is a problem with these figures. The data include official flows as a result of the intervention in the foreign exchange market by the Bank of Thailand. Despite the fact that the numbers are not statistically significant, the results consistently show that the level and the variability of these flows increased during the control episode.

Overall, our examination of the monthly data suggests that the experiences of Malaysia and Thailand were quite different. In the next section we analyze their experiences further using daily financial data.

\section{The Effectiveness of Controls: Evidence from Daily Financial Data}

In this section, we employ an eclectic variety of tests to examine whether the periods when capital controls are in place are different. First, we examine the movement of these data looking at changes in mean, variance, and persistence. We then turn our attention to testing for volatility spillovers.

\subsection{Interest rates, stock returns and exchange rates during control and crises periods}

In section 2, we provided a sketch of what theory predicts as regards the behavior of selected key financial variables following the introduction of measures that curtail international capital movements. In this section, we confront those predictions with the data from the two recent episodes. We examine the behavior of daily interest rates and changes in interest rates, stock returns, exchange rate changes, bid-ask spreads on foreign exchange, domestic-foreign interest rate differentials, and onshore-offshore interest rate differentials (where relevant).

For each of these time series we provide descriptive statistics (mean and standard errors) and test for the equality of first and second moments between the capital control and free capital mobility periods. A correlogram for the individual subperiods is also used to assess whether the 
persistence of shocks changes as a result of the change in policy. We compare the crisis and tranquil periods with the aim of assessing the extent to which observed changes in the key variables may be attributed to the crisis rather than the capital controls. Tables 4 and 5 reports the results for each country.

In the case of Malaysia (Table 4), controls seem to be associated with the kind of changes one would expect a priori if the controls were effective. The interest rate declines, and its level becomes more stable and persistent. Domestic-foreign interest rate spreads become lower and less variable. This holds for the spreads based on three, six and twelve months. Similarly, the exchange rate also becomes more stable (the ringgit was pegged to the US dollar on September 2, 1998). However, as the burden of adjustment in asset markets falls more on prices than on quantities, equity prices become more volatile. Bid-ask spreads in the foreign exchange market widen and became more volatile, reflecting reduced market liquidity.

The upper panel of figure 5 shows that bid-ask spreads are indeed more volatile, compared to spreads prior to the floatation of the Thai baht in July 1997. However, starting in July 1997, there was a sharp widening of spreads which continued to deteriorate until controls were applied. With the application of capital controls, the large increase in volatility brought on by the region's financial crisis diminished, but volatility remained above pre-crisis levels.

The results for the pre- and post-control comparisons for Thailand (Table 5) are somewhat different from those we saw for Malaysia. In both countries, the volatility of interest rates declines during the control episode; but the level of interest rates rises. Similarly, domesticforeign interest rate spreads widened, but do not become more volatile. Stock returns tended to be more variable following the introduction of capital controls consistent with the view that more 
of the burdens of adjustment fall on prices when the change in quantities is restricted. We also see an increase in exchange rate variability during the control period. Both the table and the lower panel of figure 5 shows that the bid-ask spread in the foreign exchange market widened and that volatility increased after Thailand applied capital controls.

Figure 6 plots Thai onshore-offshore interest rates at the one-month and three-month horizon. The onshore and offshore rates were for all practical purposes identical prior to May 1997. In May, the Thai authorities imposed controls on capital transactions, shielding domestic interest rates. Initially, as figure 6 shows, the controls effectively drove a wedge between onshore and offshore interest rates. The differential widened significantly and became more variable as controls squeezed liquidity in the offshore market. However, the segmentation of the market, especially after the baht floated, disappeared as the differential between the two rates narrowed.

Overall, the results between the two countries are quite different. The shared characteristics are: less variable interest rates, widening bid-ask spreads in the foreign exchange market and more variable stock prices. Otherwise, the financial variables reacted differently in the two markets, with the reactions in Malaysia conforming more to those one would anticipated. In Edison and Reinhart we also consider the movement of these variables in South Korea and the Philippines to control for whether these differences arose in part to the general turmoil created by the financial crisis and what might be associated with the introduction of capital controls. In general, we found that interest rate variability does not decline during the crisis period (they increased in Korea), equity price volatility is higher in both countries as the crisis unfolds and for the Philippines market liquidity appears to deteriorate during the crisis as bid-ask spreads on 
foreign exchange widen and become more volatile. ${ }^{9}$

\subsection{Volatility and capital controls}

The descriptive statistics discussed earlier clearly suggested that there were important differences across regimes in second moments (i.e., variances) in a high share of the financial variables analyzed. Furthermore, our theoretical priors suggested that there should be such differences. In this subsection, we focus on how capital controls and crises affect the volatility of interest rates and stock returns.

A related issue was recently examined in Edwards (1998). Using weekly interest rate data for Argentina, Chile, and Mexico, Edwards (1998) analyzed the consequences of the Mexican crisis for interest rate volatility in Argentina and Chile. The "Mexican spillover" dummies were statistically significant for Argentina, irrespective of the specification used, and uniformly insignificant for Chile. One possible interpretation of these results, he concluded, is that Chile's capital controls were effective in insulating Chile from the turmoil abroad.

In what follows, we will work with a variety of generalized autoregressive conditional heteroskedasticity $(\mathrm{GARCH})$ models to examine whether was an observed change in volatility during the capital controls episodes. ${ }^{10}$ As before, we will contrast these results to the crises episodes in the Philippines and South Korea where no controls are imposed during the crisis. We consider the following models:

\footnotetext{
${ }^{9}$ These are unchanged for South Korea.

${ }^{10}$ In all cases a GARCH $(1,1)$ model was estimated.
} 


$$
\begin{gathered}
r_{t}=\sum_{t=t-i}^{t-k} \beta_{i} r_{t-i}+\sum_{j=1}^{4} \gamma_{j} r_{j t}^{*}+\varepsilon_{t} \\
\sigma_{r t}^{2}=\omega+\text { dummy }_{c}+\alpha \varepsilon_{t-1}^{2}+\delta \sigma_{t-1}^{2}
\end{gathered}
$$

and

$$
\begin{gathered}
\Delta r_{t}=\sum_{t=t-i}^{t-k} \beta_{i} \Delta r_{t-i}+\sum_{j=1}^{4} \gamma_{j} \Delta r_{j t}^{*}+\varepsilon_{t} \\
\sigma_{\Delta r t}^{2}=\omega+\text { dummy }_{c}+\alpha \varepsilon_{t-1}^{2}+\delta \sigma_{t-1}^{2} .
\end{gathered}
$$

where the domestic nominal interest rate is denoted by $r_{t}$, in equation (1), the foreign interest rates for the other four countries in the study are denoted by the $r^{*}$, , and the random shock is denoted by $\varepsilon$. In the variance equation, $\omega$ is the mean of the variance; the lag of the mean squared residual from the mean equation (i.e., $\varepsilon_{\mathrm{t}-1}^{2}$ ) is the $\mathrm{ARCH}$ term and last period's forecast variance (i.e., $\sigma_{\mathrm{t}-1}^{2}$ ) is the GARCH term. The term $d u m m y_{c}$ is a dummy variable that takes on the value of one during the control period for Malaysia and Thailand and zero otherwise. The number of autoregressive lags, $k$, is reported for the cases $k=0,5$, and 10 . We also estimate the model in first differences $\left(\Delta r_{t}\right.$, shown in equation 2$)$ and for the case where the $r s$ and $r^{*}$ s refer to equity returns. As discussed earlier, periods of turbulence that are part of our sample of daily observations render the assumption of identically and independently distributed conditionally normal disturbances in the basic GARCH model inadequate. Given the presence of 
heteroskedastic disturbances in our sample, we use the methods described in Bollersev and Woolridge (1992) to compute the Quasi-Maximum Likelihood covariances and standard errors. The results for interest rates, changes in interest rates, and stock returns, are reported in Tables 6-8. As to the specification for nominal interest rates, while both ARCH and GARCH terms are statistically significant in Malaysia and Thailand (Table 6), the capital control dummy variable is only significant for Malaysia--although this result is not robust across alternative lag specifications. In the case of Malaysia, the controls dummy variable has the anticipated negative sign, while in the case of Thailand the sign is positive, although not statistically significant. For the two countries that did not introduce capital controls, the crisis dummy variable is not statistically significant.

Turning next to the results for the first differences of interest rates (shown in Tables 7), we find the same pattern. Among the four countries we report, the dummy variable is only significant for Malaysia for most of the lag profiles used. Finally, for daily equity price returns, the control dummy is significant and positive for Thailand, indicating the control period was associated with above-average volatility in the equity market (Table 8). However, it is difficult to attribute the increased volatility exclusively to the controls. Note that the crisis period in the Philippines (despite the absence of new capital account restrictions) was also associated with higher equity market volatility.

All in all, while the GARCH results do not point to across-the-board differences in volatility across capital account regimes, the three cases where the control dummies are significant (interest rates and interest rate changes in Malaysia and equity returns in Thailand) have the expected sign. 


\section{Final Remarks}

In this paper we examined the recent application of capital controls in Malaysia and Thailand using monthly and daily data. First, we focused on monthly data considering broad changes in economic performance, foreign exchange reserves, and capital flows. Then we examined daily financial variables, focusing on changes in those key financial variables and testing for volatility spillovers.

The conclusion that emerges from our empirical work is that the controls used in Thailand did not appear to deliver much of what they were intended. By contrast, in the case of Malaysia, the controls did align more closely with the priors of what controls were intended to achieve - namely, greater interest rate and exchange rate stability and more policy autonomy-although initially, at least, these measures did not prevent mutual funds from exiting the country.

It should be noted that one cannot draw general policy conclusions from the results of this paper as they are based on a scanty set of experiences. The results do suggest that the timing of capital controls and the types of controls that are applied might have something to do with the success of controls. One could speculate that Thailand's offshore banking center provided leakage and arbitrage opportunities that were absent in Malaysia. Further research on the effectiveness of capital controls should include more countries, classify the timing of controls, differentiate between types of controls. 


\section{References}

Bollersev, Tim, and Jeffrey M. Woolridge, 1992. "Quasi-Maximum Likelihood Estimation and Inference in Dynamic Models with Time Varying Covariances," Econometric Reviews 11, 143-172.

Calvo, Guillermo A., and Carmen M. Reinhart, 1999. "Fear of Floating," mimeograph. (College Park: University of Maryland).

Calvo, Guillermo A., and Carlos A. Rodriguez, 1979. “A Model of Exchange Rate Determination Under Currency Substitution and Rational Expectations," Journal of Political Economy 85, (June): 617-625.

Dooley, Michael, “A Survey of the Academic Literature on Controls over International Capital Transactions," IMF Staff Papers

Edison, Hali J. and Carmen M. Reinhart, 1999. “Stopping Hot Money,” unpublished paper, Federal Reserve Board.

Edwards, Sebastian, 1998. “Interest Rate Volatility, Contagion and Convergence: An Empirical Investigation of the Cases of Argentina, Chile, and Mexico"

Kaminsky, Graciela, Richard Lyons, and Sergio Schmukler, 2000, "Economic Fragility, Liquidity and Risk: The Behavior of Mutual Funds during Crises", unpublished paper, World Bank.

Kaminsky, Graciela and Carmen Reinhart, 2000, "The Center and the Periphary: Tales of Financial Turmoil, unpublished, University of Maryland.

Krugman, Paul, 1998. “Saving Asia: It's Time to Get Radical,” Fortune.

Reinhart, Vincent R., 1998. "How the Machinery of International Finance Runs with Sand in its Wheels," forthcoming in Review of International Economics. 
Reinhart, Carmen M., and Vincent R. Reinhart, 1998, "Some Lessons for policy Makers On the Mixed Blessing of Dealing with Capital Inflows," in M. Kahler, Financial Crises, (Cornell University Press).

Reinhart, Carmen M. and Todd Smith, 1998, “Too much of a Good Thing: The Macroeconomic Effects of Taxing Capital Inflows," in R. Glick, Managing Capital Flows and Exchange Rates: Perspectives from the Pacific Basin, (New York:Cambridge University Press). 
Table 1 A Chronology of Key Events

\begin{tabular}{|c|c|c|}
\hline Episode and country & Date & Key events \\
\hline \multirow[t]{10}{*}{$\begin{array}{l}\text { Thailand, Asian risis, } \\
\text { 1997-1998 }\end{array}$} & May 14 & $\begin{array}{l}\text { Bank of Thailand (BOT) introduces } \\
\text { restrictions on capital account transactions. }\end{array}$ \\
\hline & May 28 & BOT limits outright forward transactions. \\
\hline & June 2 & $\begin{array}{l}\text { BOT introduces additional measures to limit } \\
\text { capital flows. }\end{array}$ \\
\hline & June 10 & $\begin{array}{l}\text { Baht proceeds from sales of stocks required to } \\
\text { be converted at the onshore exchange rate. } \\
\text { Additional controls are introduced. }\end{array}$ \\
\hline & June 18 & $\begin{array}{l}\text { The onshore-offshore interest rate differential } \\
\text { hits a peak at } 639 \text { percent. }\end{array}$ \\
\hline & July 2 & $\begin{array}{l}\text { BOT introduces a two-tier exchange rate. } \\
\text { Thai baht is devalued. }\end{array}$ \\
\hline & September 23 & $\begin{array}{l}\text { Additional controls on invisible and current } \\
\text { account transactions are introduced. }\end{array}$ \\
\hline & January 7, 1998 & $\begin{array}{l}\text { Proceeds on exports and invisible transactions } \\
\text { and current account transfers must be } \\
\text { surrendered after } 7 \text { days (instead of } 15 \text { days). }\end{array}$ \\
\hline & January 30, 1998 & BOT ends two-tier exchange rate. \\
\hline & February 3, 1998 & $\begin{array}{l}\text { The stock market suffers its largest one-day } \\
\text { decline ( } 9.5 \text { percent). }\end{array}$ \\
\hline \multirow{6}{*}{$\begin{array}{l}\text { Malaysia, Asian } \\
\text { crisis, 1997-1998 }\end{array}$} & July 14,1997 & Interest rates peak. \\
\hline & January 5, 1998 & $\begin{array}{l}\text { Ringgit suffers its largest daily decline ( } 7.5 \\
\text { percent) against the dollar. }\end{array}$ \\
\hline & September 1,1998 & Exchange controls introduced. \\
\hline & September 2, 1998 & Exchange rate is fixed. \\
\hline & September 7, 1998 & $\begin{array}{l}\text { The stocks market suffers its largest one-day } \\
\text { decline (down } 22 \text { percent). }\end{array}$ \\
\hline & February 4, 1999 & $\begin{array}{l}\text { Exchange controls modified. New rule } \\
\text { introduced to replace one-year holding period } \\
\text { rule for portfolio capital. Under the new rules, } \\
\text { a declining scale of exit levies replaced } \\
\text { the } 12 \text {-month holding restriction on } \\
\text { repatriation of portfolio capital. }\end{array}$ \\
\hline
\end{tabular}


Table 2 Malaysia, January 1988 to March 1999: Descriptive Statistics for Monthly Data

\begin{tabular}{|c|c|c|c|c|c|c|}
\hline Variable & $\begin{array}{l}\text { Mean } \\
\text { No } \\
\text { controls }\end{array}$ & $\begin{array}{l}\text { Mean } \\
\text { Control } \\
\text { period }\end{array}$ & $\begin{array}{l}\text { Equality in } \\
\text { means t-test } \\
\text { Probability }\end{array}$ & $\begin{array}{l}\text { Standard } \\
\text { deviation } \\
\text { No controls }\end{array}$ & $\begin{array}{l}\text { Standard } \\
\text { deviation } \\
\text { Controls }\end{array}$ & $\begin{array}{l}\text { Equality in } \\
\text { variance } \\
\text { test } 1 /\end{array}$ \\
\hline Foreign Exchange Reserves & 23.5 & 24.9 & 0.26 & 2.9 & 2.7 & 0.85 \\
\hline Private Capital Flows & $\mathrm{Na}$ & $\mathrm{Na}$ & $\mathrm{Na}$ & $\mathrm{Na}$ & $\mathrm{Na}$ & $\mathrm{Na}$ \\
\hline \multicolumn{7}{|l|}{ US TIC Capital Flows: } \\
\hline \multicolumn{7}{|l|}{ Gross Flows } \\
\hline All & 2144.5 & 508 & $0.05 * *$ & 2214.6 & 242.5 & $0.003 *$ \\
\hline All bonds & 1838.9 & 430.9 & $0.07 * *$ & 2054.3 & 212.2 & $0.03 *$ \\
\hline US Pvt \& for. bonds & 142.3 & 49.1 & .29 & 227.4 & 49.5 & .23 \\
\hline Equity & 327.8 & 124.3 & 0.1 & 325.0 & 51.7 & $0.08 * *$ \\
\hline \multicolumn{7}{|l|}{ Net Flows } \\
\hline All & -58.5 & 99.2 & 0.3 & 393.2 & 234.8 & 0.9 \\
\hline All bonds & -45.9 & 74.0 & 0.4 & 395.2 & 193.4 & 0.9 \\
\hline US Pvt \& for. bonds - lvl & -37.5 & -6.6 & 0.7 & 211.9 & 38.2 & 0.7 \\
\hline Equity & -17.5 & 19.4 & 0.2 & 66.4 & 62.7 & 0.4 \\
\hline \multicolumn{7}{|l|}{ Malay Outflow } \\
\hline Equity & 155.1 & 71.9 & 0.2 & 159.4 & 56.3 & $0.08 * *$ \\
\hline \multicolumn{7}{|l|}{ Malay Inflow } \\
\hline Equity & 172.6 & 52.4 & $0.07 * *$ & 172.1 & 11.5 & 0.19 \\
\hline
\end{tabular}

Notes to Table: Control Period is September 1998 to end of sample. (*) denotes significant at 5 percent level and $(* *)$ denotes significant at the 10 percent level. Reported test is based on Siegel-Tukey test. 
Table 3 Thailand, January 1988 to March 1999: Descriptive Statistics for Monthly Capital Flow Data

\begin{tabular}{|c|c|c|c|c|c|c|}
\hline Variable & $\begin{array}{l}\text { Mean } \\
\text { No } \\
\text { controls }\end{array}$ & $\begin{array}{l}\text { Mean } \\
\text { Control } \\
\text { period } \\
\end{array}$ & $\begin{array}{l}\text { Equality in } \\
\text { means t-test } \\
\text { Probability }\end{array}$ & $\begin{array}{l}\text { Standard } \\
\text { deviation } \\
\text { No controls } \\
\end{array}$ & $\begin{array}{l}\text { Standard } \\
\text { deviation } \\
\text { Control } \\
\end{array}$ & $\begin{array}{l}\text { Equality in } \\
\text { variance } \\
\text { test } 1 /\end{array}$ \\
\hline Foreign Exchange Reserves & 32.8 & 28.2 & $0.02 *$ & 5.3 & 2.8 & 0.5 \\
\hline Private Capital Flows & 11907 & -54366 & $0.00 *$ & 36776 & 71554 & $0.01 *$ \\
\hline \multicolumn{7}{|l|}{ US TIC Capital Flows: } \\
\hline \multicolumn{7}{|l|}{ Gross Flows } \\
\hline All & 1629.4 & 3243.9 & $0.00 *$ & 1566.4 & 1672.4 & 0.51 \\
\hline All bonds & 1577.2 & 3133.8 & $0.00 *$ & 1560.0 & 1660.3 & 0.52 \\
\hline US Pvt \& for. bonds & 11.1 & 25.7 & $0.0^{*}$ & 11.6 & 12.7 & $0.03 *$ \\
\hline Equity & 55.7 & 111.5 & $0.09 * *$ & 88.7 & 175.2 & 0.46 \\
\hline \multicolumn{7}{|l|}{ Net Flows } \\
\hline All & 476.9 & 585.6 & 0.66 & 711.3 & 884.9 & $0.00 *$ \\
\hline All bonds & 490.3 & 672.4 & 0.47 & 717.6 & 891.8 & $0.00 *$ \\
\hline US Pvt \& for. bonds & 1.3 & -1.3 & 0.3 & 7.2 & 7.4 & 0.9 \\
\hline Equity & -12.4 & -84.8 & $0.01 *$ & 79.7 & 161.8 & 0.41 \\
\hline \multicolumn{7}{|l|}{ Malay Outflow } \\
\hline Equity- & 21.6 & 13.3 & 0.43 & 31.2 & 14.3 & 0.48 \\
\hline \multicolumn{7}{|l|}{ Malay Inflow } \\
\hline Equity & 34.0 & 98.2 & $0.03 *$ & 78.3 & 168.1 & 0.72 \\
\hline
\end{tabular}

Notes to Table: Control Period is May 1997 to January 1998. (*) denotes significant at 5 percent level and $(* *)$ denotes significant at the 10 percent level. Reported test is based on Siegel-Tukey test. 
Table 4 Malaysia, January 1, 1996 to July 23, 1999 : Descriptive Statistics for Daily Data

\begin{tabular}{|c|c|c|c|c|c|c|c|c|}
\hline Variable & $\begin{array}{l}\text { Mean } \\
\text { No } \\
\text { controls }\end{array}$ & $\begin{array}{l}\text { Mean } \\
\text { Control } \\
\text { period }\end{array}$ & $\begin{array}{l}\text { Equality in } \\
\text { means t- } \\
\text { test } \\
\text { Probability }\end{array}$ & $\begin{array}{l}\text { Standard } \\
\text { deviation } \\
\text { No } \\
\text { controls }\end{array}$ & $\begin{array}{l}\text { Standard } \\
\text { deviation } \\
\text { Control } \\
\text { period }\end{array}$ & $\begin{array}{l}\text { Equality } \\
\text { in } \\
\text { variance } \\
\text { test } 1 /\end{array}$ & $\begin{array}{l}\text { Auto } \\
\text { correlation } \\
\text { No } \\
\text { controls } \\
\end{array}$ & $\begin{array}{l}\text { Auto } \\
\text { correlation } \\
\text { Control } \\
\text { period } \\
\end{array}$ \\
\hline $\begin{array}{l}\text { Interest } \\
\text { Rate }\end{array}$ & 8.328 & 5.720 & $0.000 *$ & 1.549 & 1.452 & $0.000 *$ & 0.935 & 0.956 \\
\hline $\begin{array}{l}\text { Change in } \\
\text { interest } \\
\text { rate }\end{array}$ & 0.121 & -0.545 & $0.004 *$ & 0.386 & 0.140 & 0.157 & 0.212 & 0.219 \\
\hline $\begin{array}{l}\text { Domestic/ } \\
\text { foreign } \\
\text { interest } \\
\text { rate } \\
\text { spread: } \\
\text { 3-month }\end{array}$ & 3.192 & 1.473 & $0.000 *$ & 1.490 & 1.469 & $0.002 *$ & 0.912 & 0.934 \\
\hline $\begin{array}{l}\text { Domestic/ } \\
\text { foreign } \\
\text { interest } \\
\text { rate } \\
\text { spread: } \\
\text { 6-month }\end{array}$ & 3.163 & 1.491 & $0.000 *$ & 1.586 & 1.463 & $0.000 *$ & 0.914 & 0.940 \\
\hline $\begin{array}{l}\text { Domestic/ } \\
\text { foreign } \\
\text { interest } \\
\text { rate } \\
\text { spread: } \\
\text { 12-month }\end{array}$ & 3.045 & 1.541 & $0.000 *$ & 1.699 & 1.493 & $0.000 *$ & 0.925 & 0.942 \\
\hline $\begin{array}{l}\text { Stock } \\
\text { returns }\end{array}$ & -0.194 & 0.652 & $0.000 *$ & 2.089 & 3.385 & $0.000 *$ & -0.080 & 0.133 \\
\hline $\begin{array}{l}\text { Exchange } \\
\text { rate } \\
\text { changes }\end{array}$ & 0.064 & -0.011 & 0.405 & 1.241 & 0.166 & $0.000 *$ & -0.011 & 0.049 \\
\hline $\begin{array}{l}\text { Bid-ask } \\
\text { spread }\end{array}$ & -0.006 & -0.008 & $0.012 *$ & 0.015 & 0.006 & $0.000 *$ & 0.153 & 0.275 \\
\hline
\end{tabular}

$\overline{\text { 1/ Siegel-Tukey test is reported. Other test results are available from the authors upon request. }}$ 
Table 5 Thailand, January 1, 1996 to July 23, 1999: Descriptive Statistics for Daily Data

\begin{tabular}{|c|c|c|c|c|c|c|c|c|}
\hline Variable & $\begin{array}{l}\text { Mean } \\
\text { No } \\
\text { controls }\end{array}$ & $\begin{array}{l}\text { Mean } \\
\text { Control } \\
\text { period }\end{array}$ & $\begin{array}{l}\text { Equality in } \\
\text { means t- } \\
\text { test } \\
\text { Probability }\end{array}$ & $\begin{array}{l}\text { Standard } \\
\text { deviation } \\
\text { No } \\
\text { controls }\end{array}$ & $\begin{array}{l}\text { Standard } \\
\text { deviation } \\
\text { Control } \\
\text { period }\end{array}$ & $\begin{array}{l}\text { Equality } \\
\text { in } \\
\text { variance } \\
\text { test } 1 /\end{array}$ & $\begin{array}{l}\text { Auto } \\
\text { correlation } \\
\text { No } \\
\text { controls }\end{array}$ & $\begin{array}{l}\text { Auto } \\
\text { correlation } \\
\text { Control } \\
\text { period }\end{array}$ \\
\hline $\begin{array}{l}\text { Interest } \\
\text { Rate }\end{array}$ & 12.461 & 20.920 & $0.000 *$ & 5.779 & 3.829 & $0.000 *$ & 0.930 & 0.912 \\
\hline $\begin{array}{l}\text { Change in } \\
\text { interest } \\
\text { rate }\end{array}$ & -0.0318 & 0.073 & 0.067 & 0.600 & 0.818 & $0.000 *$ & -0.061 & 0.202 \\
\hline $\begin{array}{l}\text { Domestic/ } \\
\text { foreign } \\
\text { interest } \\
\text { rate } \\
\text { spread: } \\
\text { 1-month }\end{array}$ & 7.704 & 15.941 & $0.000 *$ & 5.609 & 3.804 & 0.075 & & \\
\hline $\begin{array}{l}\text { Stock } \\
\text { returns }\end{array}$ & -0.114 & 0.019 & 0.510 & 2.153 & 2.923 & $0.000 *$ & 0.115 & 0.258 \\
\hline $\begin{array}{l}\text { Exchange } \\
\text { rate } \\
\text { changes }\end{array}$ & -0.047 & 0.361 & $0.000^{*}$ & 0.828 & 2.623 & $0.000 *$ & 0.047 & -0.123 \\
\hline $\begin{array}{l}\text { Bid-ask } \\
\text { spread }\end{array}$ & -0.074 & -0.313 & $0.000 *$ & 0.111 & 0.978 & $0.033 *$ & 0.318 & 0.474 \\
\hline \multicolumn{9}{|c|}{ Onshore-offshore interest rate spreads } \\
\hline Overnight & 1.336 & 16.730 & $0.000 *$ & 4.878 & 85.488 & $0.000 *$ & 0.332 & 0.872 \\
\hline Weekly & 3.978 & 17.004 & $0.000 *$ & 7.900 & 58.323 & $0.000 *$ & 0.725 & 0.882 \\
\hline $\begin{array}{l}\text { One- } \\
\text { month }\end{array}$ & 4.381 & 11.633 & $0.000 *$ & 6.420 & 22.955 & $0.000 *$ & 0.806 & 0.869 \\
\hline $\begin{array}{l}\text { Three- } \\
\text { month }\end{array}$ & 4.067 & 6.988 & $0.000 *$ & 4.923 & 6.937 & $0.021 *$ & 0.845 & 0.867 \\
\hline $\begin{array}{l}\text { Six- } \\
\text { month }\end{array}$ & 3.655 & 5.097 & $0.035^{*}$ & 7.973 & 6.136 & $0.000 *$ & 0.158 & 0.850 \\
\hline 12-month & 2.807 & 3.916 & $0.000 *$ & 2.978 & 3.752 & $0.000 *$ & 0.882 & 0.813 \\
\hline
\end{tabular}

1/ Siegel-Tukey test is reported. Other test results are available from the authors upon request. 
Table 6 Daily Interest Rates Variance Equation: Volatility Spillovers With and Without Capital Controls Bollersev-Woolridge robust standard errors and covariance, $\operatorname{GARCH}(1,1)$

\begin{tabular}{|c|c|c|c|}
\hline $\begin{array}{l}\text { Number of } \\
\text { autoregressive lags } \\
\text { included }\end{array}$ & $\mathrm{ARCH}(1)$ & GARCH (1) & Controls dummy \\
\hline \multicolumn{4}{|l|}{ Malaysia } \\
\hline 0 & $\begin{array}{c}0.503 \\
(0.045)^{*}\end{array}$ & $\begin{array}{c}0.559 \\
(0.000) *\end{array}$ & $\begin{array}{l}-0.004 \\
(0.129)\end{array}$ \\
\hline 5 & $\begin{array}{l}1.464 \\
(0.000)^{*}\end{array}$ & $\begin{array}{c}0.117 \\
(0.060) *\end{array}$ & $\begin{array}{l}-0.005 \\
(0.131)\end{array}$ \\
\hline 10 & $\begin{array}{l}1.442 \\
(0.003)^{*}\end{array}$ & $\begin{array}{c}0.136 \\
(0.037) *\end{array}$ & $\begin{array}{l}-0.008 \\
(0.021)^{*}\end{array}$ \\
\hline \multicolumn{4}{|l|}{ Thailand } \\
\hline 0 & $\begin{array}{c}0.331 \\
(0.081)^{*}\end{array}$ & $\begin{array}{c}0.603 \\
(0.000) *\end{array}$ & $\begin{array}{c}0.073 \\
(0.133)\end{array}$ \\
\hline 5 & $\begin{array}{c}0.342 \\
(0.062) *\end{array}$ & $\begin{array}{c}0.582 \\
(0.000) *\end{array}$ & $\begin{array}{c}0.074 \\
(0.109)\end{array}$ \\
\hline 10 & $\begin{array}{c}0.355 \\
(0.055) *\end{array}$ & $\begin{array}{c}0.576 \\
(0.000)^{*}\end{array}$ & $\begin{array}{c}0.072 \\
(0.111)\end{array}$ \\
\hline \multicolumn{4}{|l|}{ Philippines } \\
\hline 0 & $\begin{array}{c}0.099 \\
(0.363)\end{array}$ & $\begin{array}{l}0.697 \\
(0.011) *\end{array}$ & $\begin{array}{l}-0.011 \\
(0.506)\end{array}$ \\
\hline 5 & $\begin{array}{c}2.635 \\
(0.002)^{*}\end{array}$ & $\begin{array}{c}0.109 \\
(0.036) *\end{array}$ & $\begin{array}{l}-0.045 \\
(0.243)\end{array}$ \\
\hline 10 & $\begin{array}{l}4.295 \\
(0.001)^{*}\end{array}$ & $\begin{array}{c}0.003 \\
(0.489)\end{array}$ & $\begin{array}{l}-0.046 \\
(0.236)\end{array}$ \\
\hline \multicolumn{4}{|l|}{ South Korea } \\
\hline 0 & $\begin{array}{c}0.347 \\
(0.018) *\end{array}$ & $\begin{array}{c}0.046 \\
(0.000)^{*}\end{array}$ & $\begin{array}{c}0.007 \\
(0.860)\end{array}$ \\
\hline 5 & $\begin{array}{c}0.278 \\
(0.012) *\end{array}$ & $\begin{array}{c}0.816 \\
(0.000) *\end{array}$ & $\begin{array}{c}0.001 \\
(0.813)\end{array}$ \\
\hline 10 & $\begin{array}{c}0.275 \\
(0.014) * \\
\end{array}$ & $\begin{array}{c}0.816 \\
(0.000)^{*} \\
\end{array}$ & $\begin{array}{c}0.001 \\
(0.775) \\
\end{array}$ \\
\hline
\end{tabular}

Notes to table: In all cases an ARCH (1) or a GARCH(1,1) model was estimated. The controls dummy variable takes on the value of one during the control period for Malaysia, and Thailand and zero otherwise. For the Philippines and South Korea the dummy variable takes on a value of one during the crisis period and zero otherwise. 
Table 7 Daily Interest Rate Changes Variance Equation:Volatility Spillovers With and Without Capital Controls Bollersev-Woolridge robust standard errors and covariance, $\operatorname{GARCH}(1,1)$

\begin{tabular}{|c|c|c|c|}
\hline $\begin{array}{c}\text { Number of } \\
\text { autoregressive lags } \\
\text { included }\end{array}$ & $\mathrm{ARCH}(1)$ & GARCH (1) & Controls dummy \\
\hline \multicolumn{4}{|l|}{ Malaysia } \\
\hline 0 & $\begin{array}{c}0.465 \\
(0.041) *\end{array}$ & $\begin{array}{c}0.583 \\
(0.000) *\end{array}$ & $\begin{array}{l}-0.004 \\
(0.119)\end{array}$ \\
\hline 5 & $\begin{array}{c}0.543 \\
(0.050) *\end{array}$ & $\begin{array}{c}0.495 \\
(0.000) *\end{array}$ & $\begin{array}{l}-0.005 \\
(0.100)^{*}\end{array}$ \\
\hline 10 & $\begin{array}{l}1.492 \\
(0.001) *\end{array}$ & $\begin{array}{c}0.083 \\
(0.079)^{*}\end{array}$ & $\begin{array}{l}-0.009 \\
(0.025)^{*}\end{array}$ \\
\hline \multicolumn{4}{|l|}{ Thailand } \\
\hline 0 & $\begin{array}{c}0.316 \\
(0.090)^{*}\end{array}$ & $\begin{array}{c}0.601 \\
(0.000)^{*}\end{array}$ & $\begin{array}{c}0.078 \\
(0.136)\end{array}$ \\
\hline 5 & $\begin{array}{c}0.338 \\
(0.067)^{*}\end{array}$ & $\begin{array}{c}0.571 \\
(0.000)^{*}\end{array}$ & $\begin{array}{c}0.078 \\
(0.112)\end{array}$ \\
\hline 10 & $\begin{array}{c}0.345 \\
(0.058)^{*}\end{array}$ & $\begin{array}{c}0.577 \\
(0.000)^{*}\end{array}$ & $\begin{array}{c}0.072 \\
(0.111)\end{array}$ \\
\hline \multicolumn{4}{|l|}{ Philippines } \\
\hline 0 & $\begin{array}{c}0.108 \\
(0.400)\end{array}$ & $\begin{array}{c}0.664 \\
(0.078) *\end{array}$ & $\begin{array}{l}-0.013 \\
(0.529)\end{array}$ \\
\hline 5 & $\begin{array}{c}0.100 \\
(0.419)\end{array}$ & $\begin{array}{c}0.666 \\
(0.064)^{*}\end{array}$ & $\begin{array}{l}-0.012 \\
(0.524)\end{array}$ \\
\hline 10 & $\begin{array}{c}0.157 \\
(0.292)\end{array}$ & $\begin{array}{c}0.490 \\
(0.073)\end{array}$ & $\begin{array}{l}-0.002 \\
(0.389)\end{array}$ \\
\hline \multicolumn{4}{|l|}{ South Korea } \\
\hline 0 & $\begin{array}{c}0.350 \\
(0.030) *\end{array}$ & $\begin{array}{c}0.804 \\
(0.000) *\end{array}$ & $\begin{array}{l}-0.001 \\
(0.944)\end{array}$ \\
\hline 5 & $\begin{array}{c}0.323 \\
(0.029)^{*}\end{array}$ & $\begin{array}{c}0.815 \\
(0.000)^{*}\end{array}$ & $\begin{array}{l}-0.001 \\
(0.847)\end{array}$ \\
\hline 10 & $\begin{array}{c}0.327 \\
(0.026) *\end{array}$ & $\begin{array}{c}0.808 \\
(0.000) *\end{array}$ & $\begin{array}{l}-0.001 \\
(0.988)\end{array}$ \\
\hline
\end{tabular}

Notes to table: In all cases an ARCH (1) or a GARCH(1,1) model was estimated. The controls dummy variable takes on the value of one during the control period for Malaysia, and Thailand and zero otherwise. For the Philippines and South Korea the dummy variable takes on a value of one during the crisis period and zero otherwise. 
Table 8 Daily Stock Returns Variance Equation: Volatility Spillovers With and Without Capital Controls Bollersev-Woolridge robust standard errors and covariance, $\operatorname{GARCH}(1,1)$

\begin{tabular}{|c|c|c|c|}
\hline $\begin{array}{c}\text { Number of } \\
\text { autoregressive lags } \\
\text { included }\end{array}$ & $\mathrm{ARCH}(1)$ & GARCH (1) & Controls dummy \\
\hline \multicolumn{4}{|l|}{ Malaysia } \\
\hline 0 & $\begin{array}{c}0.131 \\
(0.000) *\end{array}$ & $\begin{array}{c}0.882 \\
(0.000) *\end{array}$ & $\begin{array}{c}0.001 \\
(0.708)\end{array}$ \\
\hline 5 & $\begin{array}{l}0.129 \\
(0.000) *\end{array}$ & $\begin{array}{c}0.884 \\
(0.000) *\end{array}$ & $\begin{array}{c}0.001 \\
(0.738)\end{array}$ \\
\hline 10 & $\begin{array}{c}0.146 \\
(0.000) *\end{array}$ & $\begin{array}{c}0.869 \\
(0.000) *\end{array}$ & $\begin{array}{c}0.001 \\
(0.652)\end{array}$ \\
\hline \multicolumn{4}{|l|}{ Thailand } \\
\hline 0 & $\begin{array}{c}0.140 \\
(0.000)^{*}\end{array}$ & $\begin{array}{c}0.818 \\
(0.000)^{*}\end{array}$ & $\begin{array}{c}0.002 \\
(0.082)^{*}\end{array}$ \\
\hline 5 & $\begin{array}{c}0.148 \\
(0.067)^{*}\end{array}$ & $\begin{array}{c}0.805 \\
(0.000)^{*}\end{array}$ & $\begin{array}{c}0.002 \\
(0.072) *\end{array}$ \\
\hline 10 & $\begin{array}{c}0.137 \\
(0.000)^{*}\end{array}$ & $\begin{array}{c}0.828 \\
(0.000)^{*}\end{array}$ & $\begin{array}{c}0.002 \\
(0.079)^{*}\end{array}$ \\
\hline \multicolumn{4}{|l|}{ Philippines } \\
\hline 0 & $\begin{array}{c}0.184 \\
(0.000) *\end{array}$ & $\begin{array}{c}0.781 \\
(0.000) *\end{array}$ & $\begin{array}{l}0.001 \\
(0.071) *\end{array}$ \\
\hline 5 & $\begin{array}{l}0.198 \\
(0.000) *\end{array}$ & $\begin{array}{c}0.766 \\
(0.000) *\end{array}$ & $\begin{array}{c}0.001 \\
(0.082) *\end{array}$ \\
\hline 10 & $\begin{array}{c}0.216 \\
(0.000)^{*}\end{array}$ & $\begin{array}{c}0.742 \\
(0.000) *\end{array}$ & $\begin{array}{c}0.001 \\
(0.056) *\end{array}$ \\
\hline \multicolumn{4}{|l|}{ South Korea } \\
\hline 0 & $\begin{array}{c}0.086 \\
(0.000) *\end{array}$ & $\begin{array}{c}0.910 \\
(0.000) *\end{array}$ & $\begin{array}{c}0.001 \\
(0.156)\end{array}$ \\
\hline 5 & $\begin{array}{c}0.059 \\
(0.001) *\end{array}$ & $\begin{array}{c}0.940 \\
(0.000) *\end{array}$ & $\begin{array}{c}0.001 \\
(0.187)\end{array}$ \\
\hline 10 & $\begin{array}{c}0.061 \\
(0.001)^{*}\end{array}$ & $\begin{array}{c}0.938 \\
(0.000) *\end{array}$ & $\begin{array}{c}0.001 \\
(0.199) \\
\end{array}$ \\
\hline
\end{tabular}

Notes to table: In all cases an ARCH (1) or a GARCH(1,1) model was estimated. The controls dummy variable takes on the value of one during the control period for Malaysia, and Thailand and zero otherwise. For the Philippines and South Korea the dummy variable takes on a value of one during the crisis period and zero otherwise. 
Figure 1: Malaysia
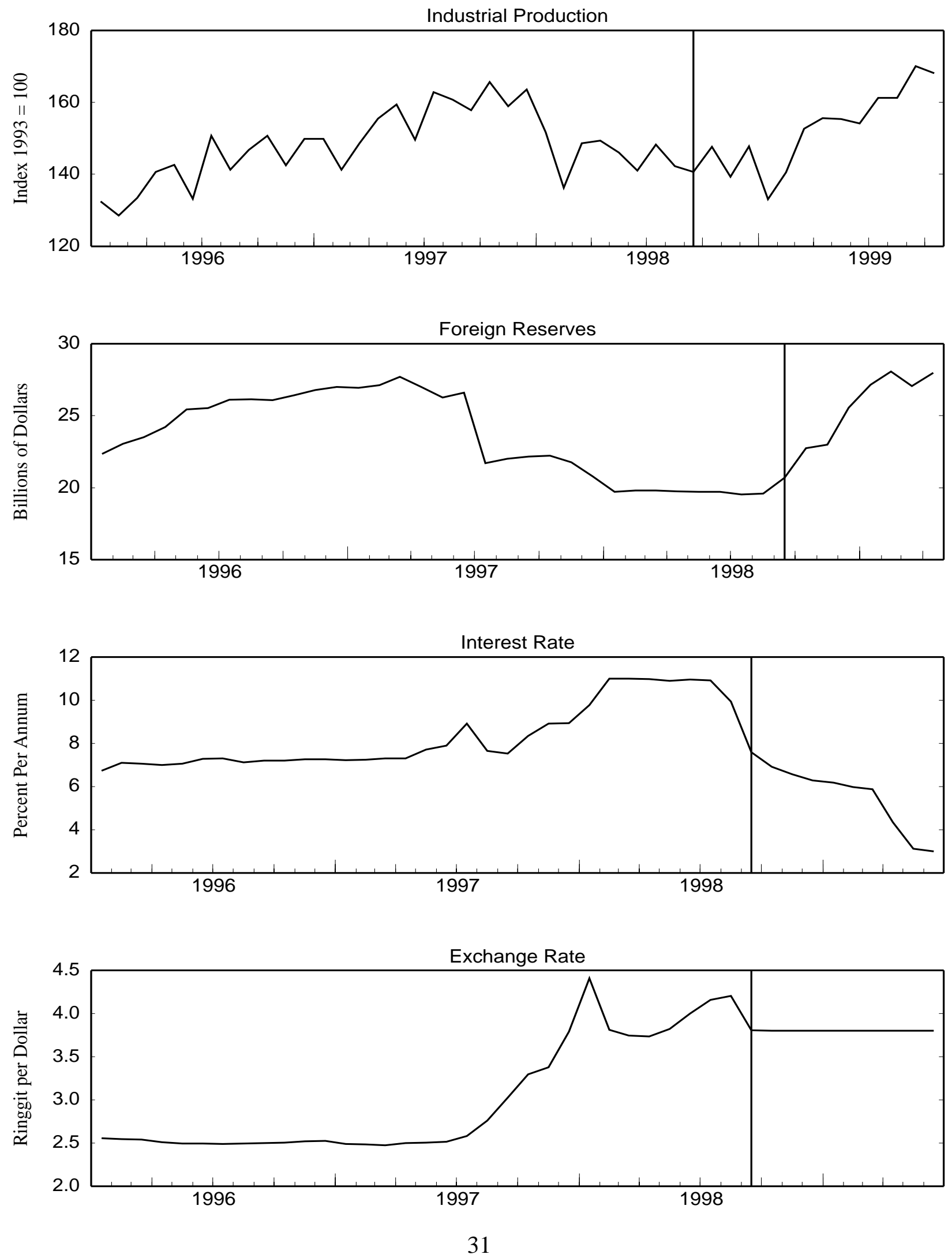


\section{Figure 2 Mutual Funds Flows: Global Spillovers}

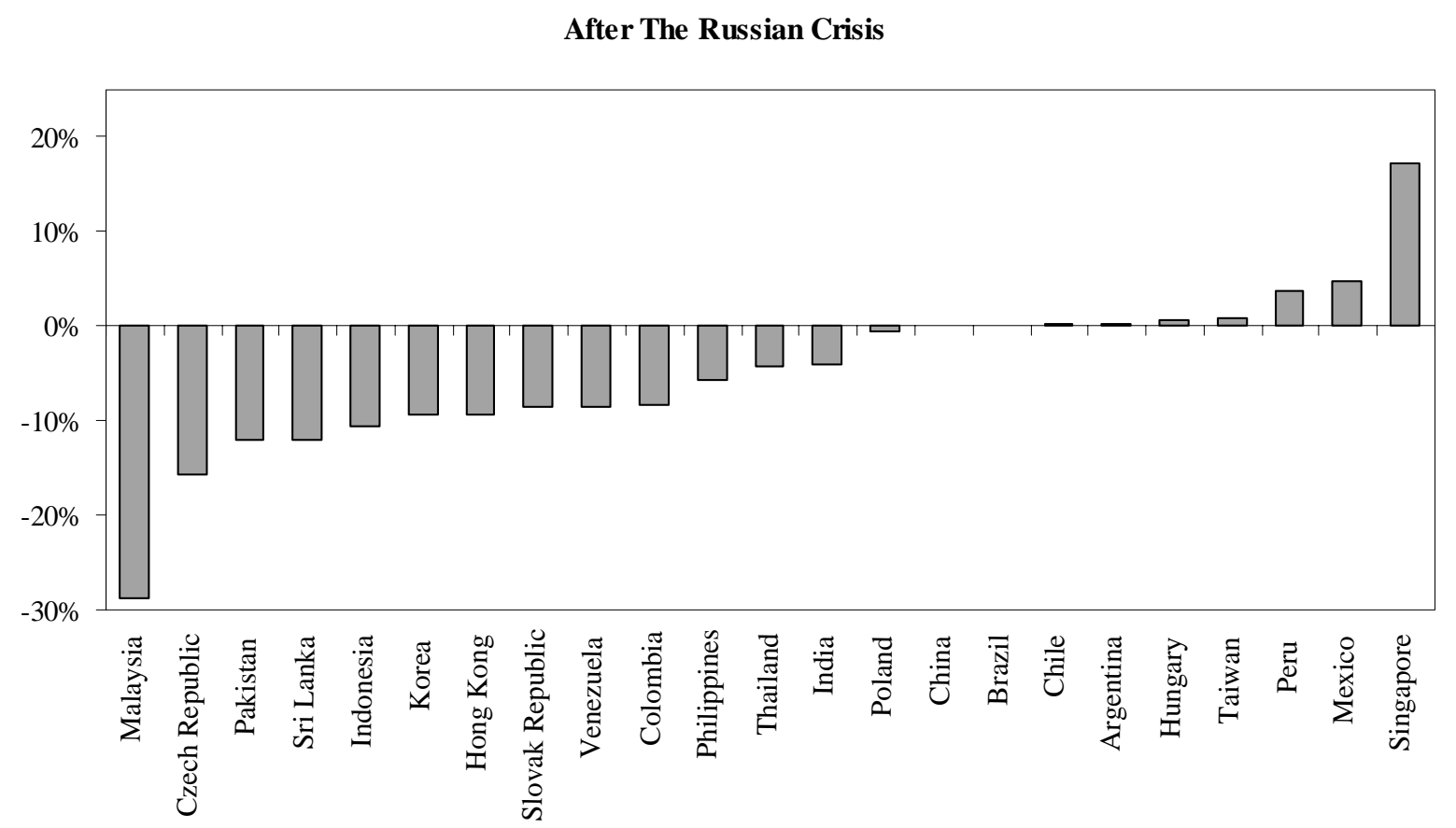

Notes: The Russian crisis began August 1998. Mutual fund flows are the average net buying/selling (as percentage of the end of the preceding quarter holdings) in the two quarters following the outbreak of the crisis, relative to the sample average.

Source: Kaminsky, Lyons, and Schmukler (2000) "Economic Fragility, Liquidity, and Risk: The Behavior of Mutual Funds during Crises". 
Figure 3: Thailand
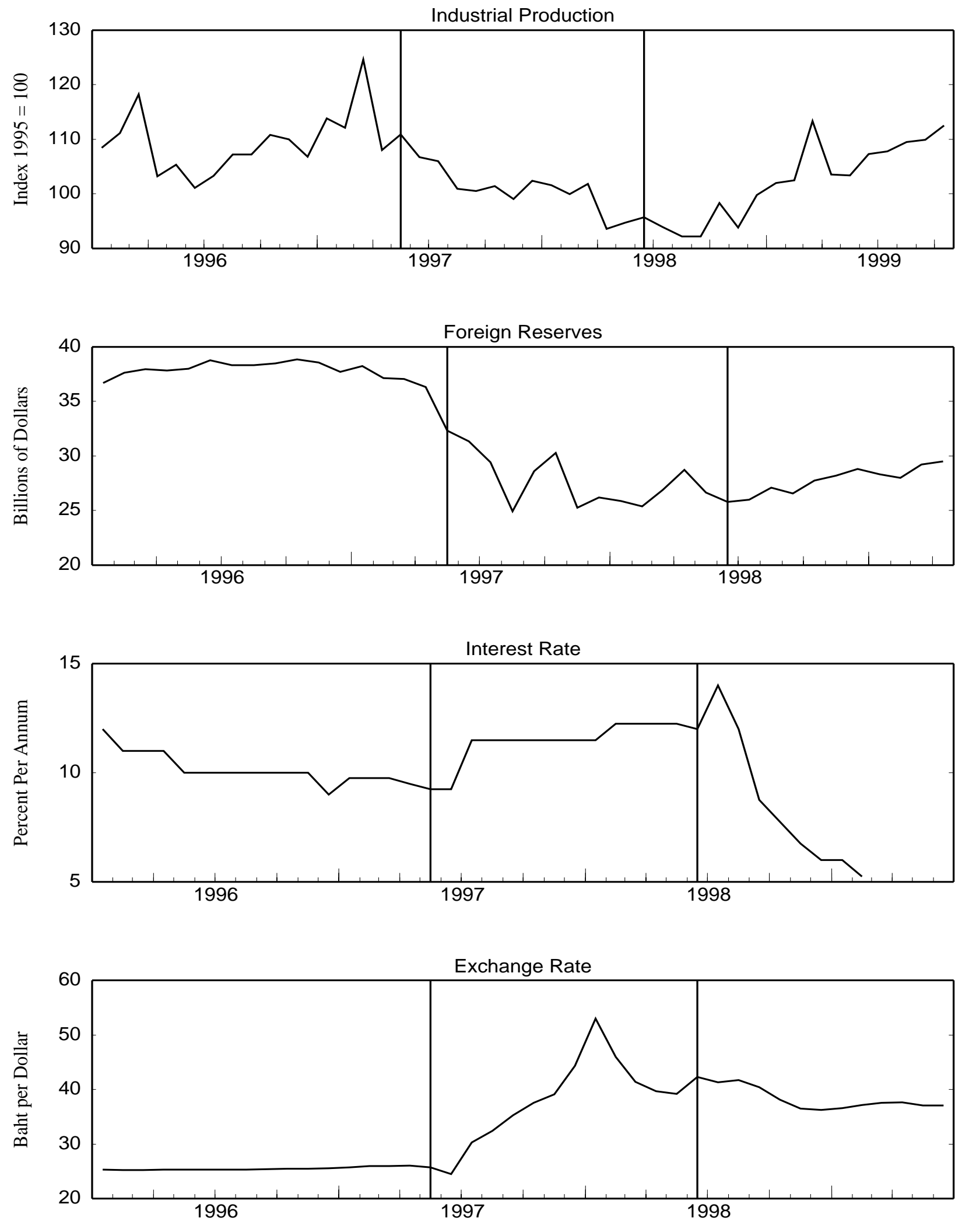
Figure 4
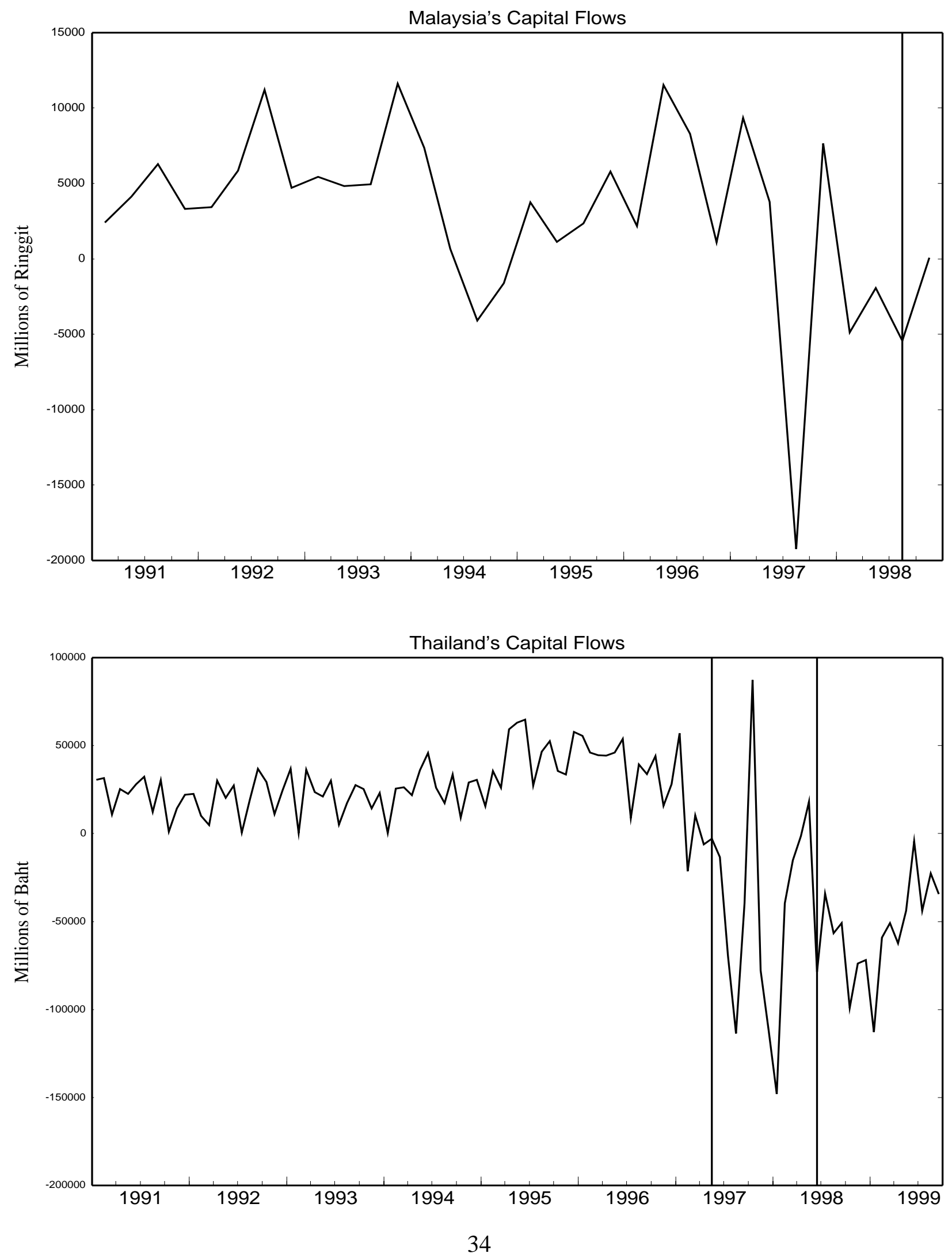
Figure 5
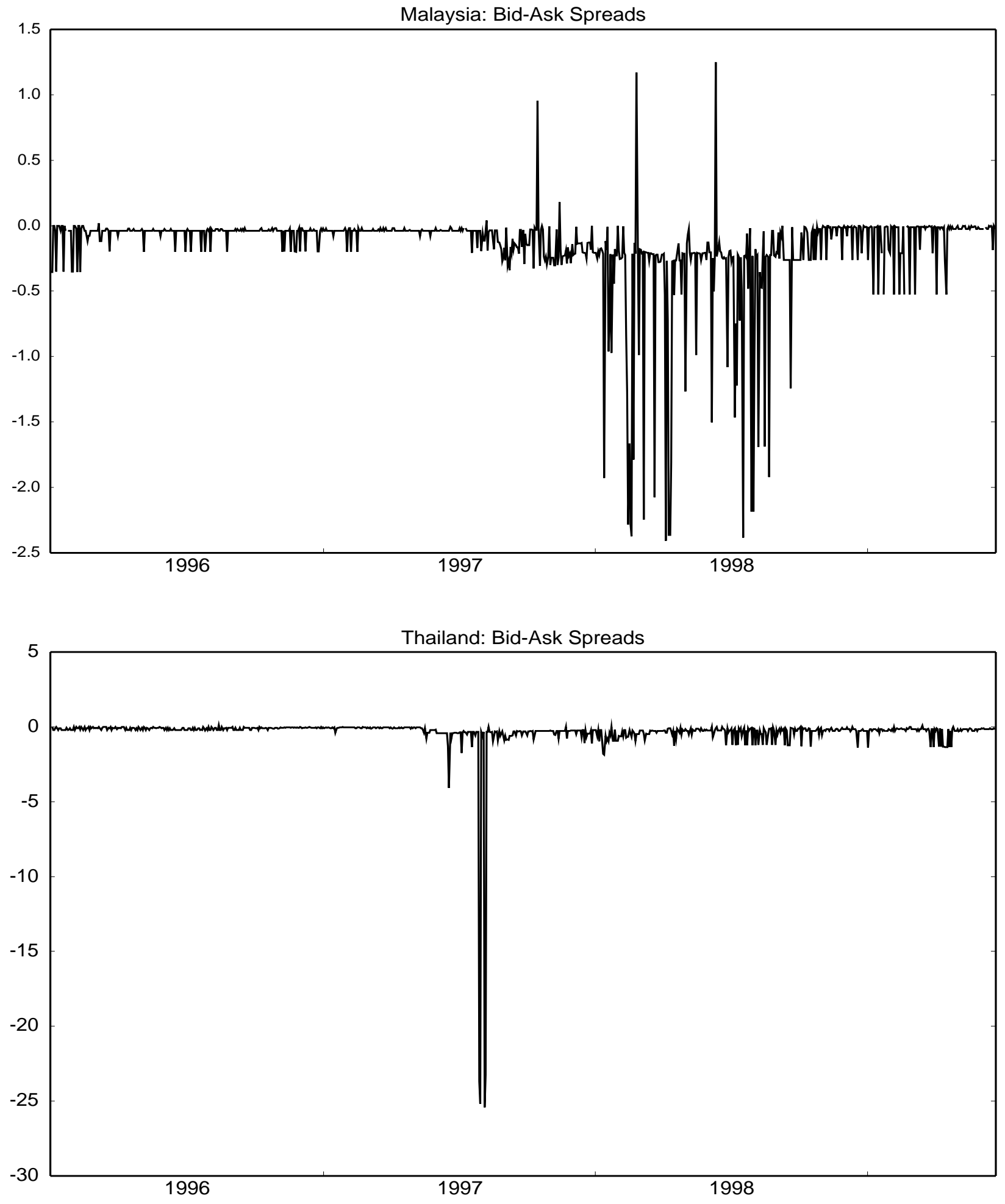

Note: Daily bid-ask spread over midpoint spot rate in percent 
Figure 6

Thailand

One-Month Interest Rates: Onshore/Offshore

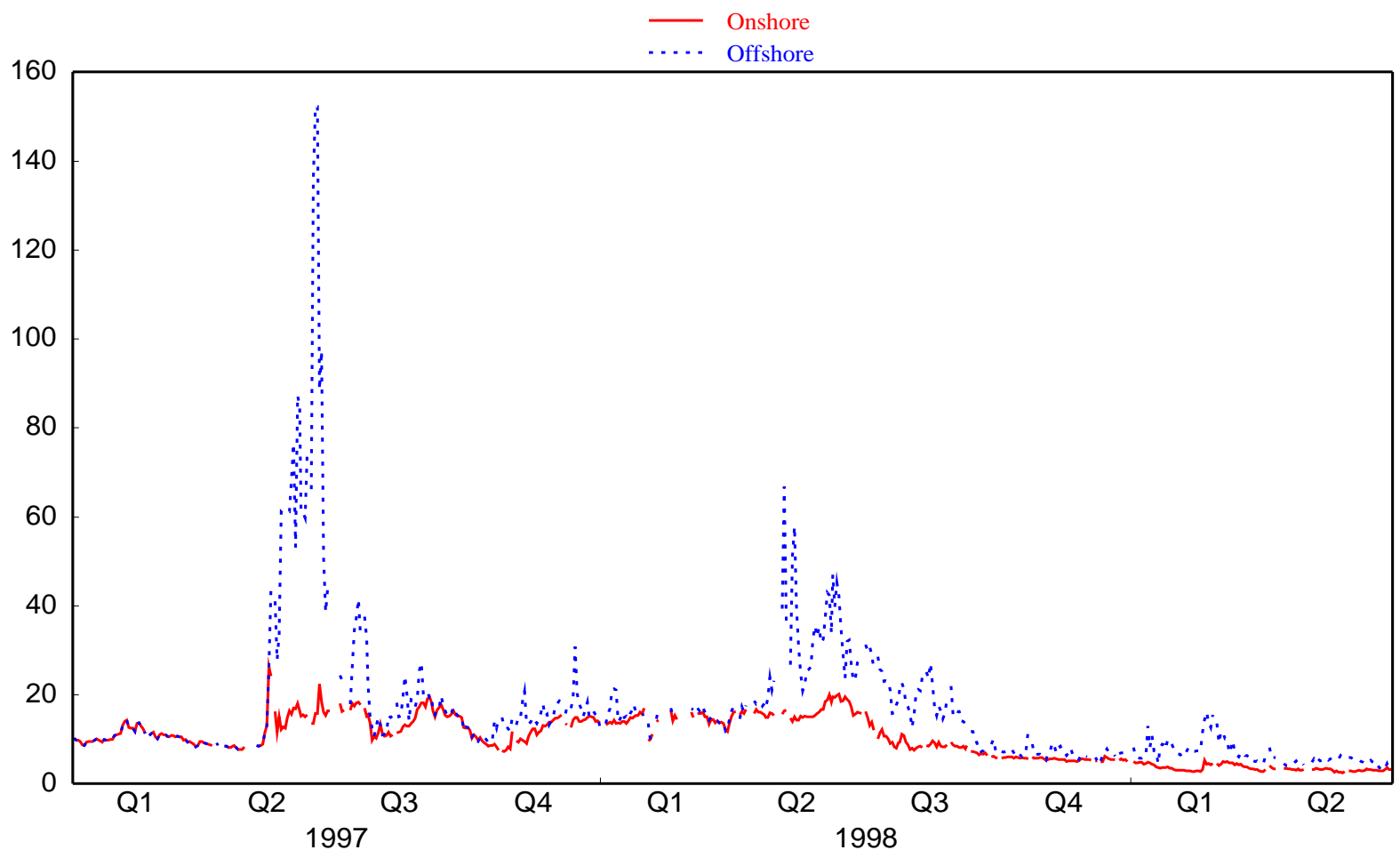

Three-Month Interest Rates: Onshore/Offshore

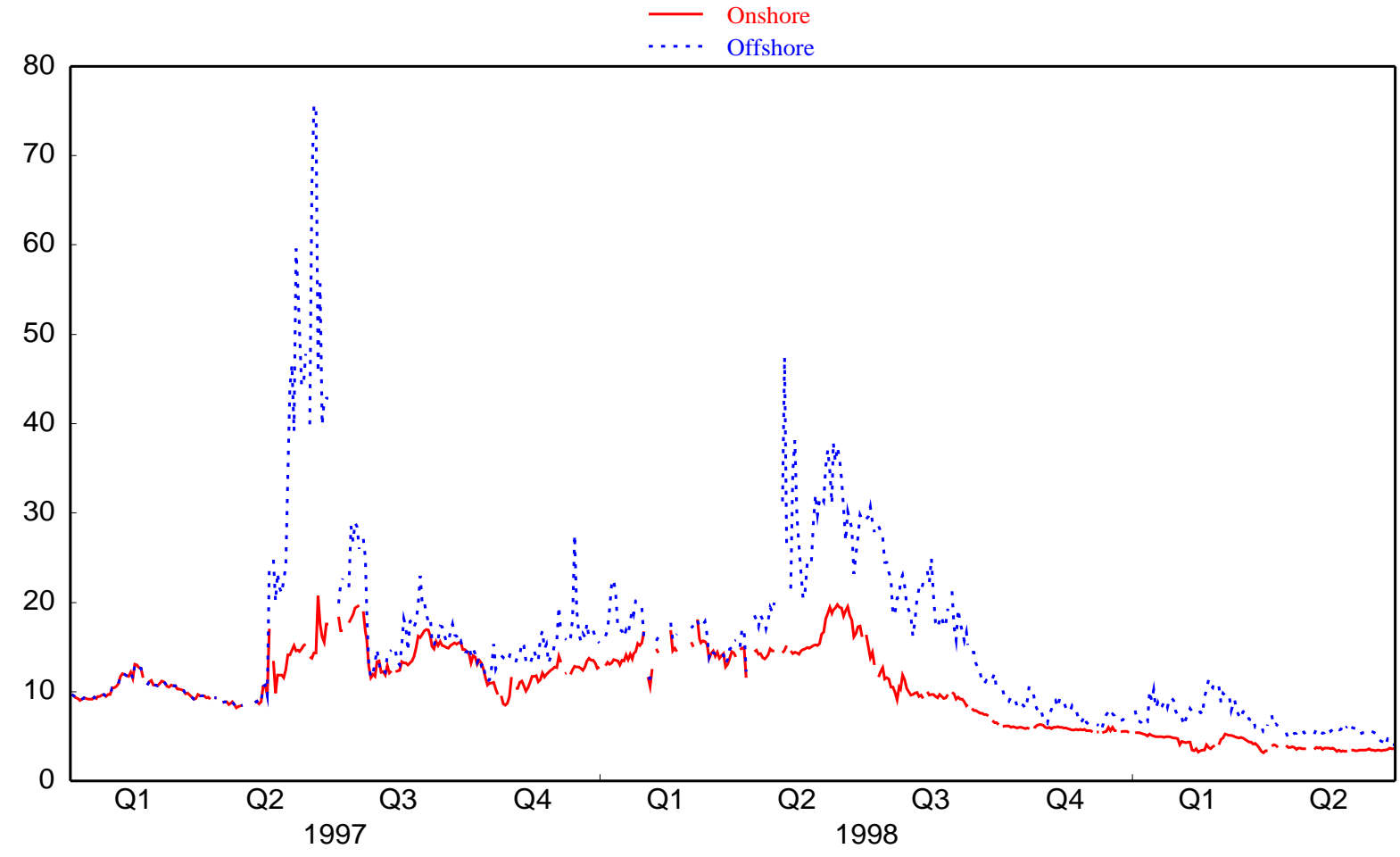

